\title{
Article \\ Factors Affecting Augmented Reality Adoption in the Retail Industry
}

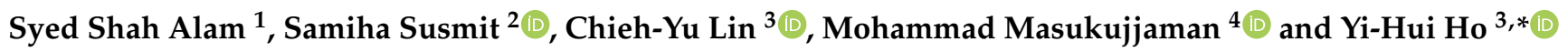 \\ 1 Faculty of Business, Finance and Information Technology, MAHSA University, Jenjarom 42610, Malaysia; \\ syed@mahsa.edu.my \\ 2 Faculty of Information Science and Technology, The National University of Malaysia, Bangi 43600, Malaysia; \\ samiha.susmit17@gmail.com \\ 3 Department of International Business, Chang Jung Christian University, Tainan 71101, Taiwan; \\ jylin@mail.cjcu.edu.tw \\ 4 Department of Business Administration, Northern University Bangladesh, Dhaka 1205, Bangladesh; \\ masuknub@gmail.com \\ * Correspondence: vicky@mail.cjcu.edu.tw
}

\section{check for}

updates

Citation: Alam, S.S.; Susmit, S.; Lin, C.-Y.; Masukujjaman, M.; Ho, Y.-H. Factors Affecting Augmented Reality Adoption in the Retail Industry. J. Open Innov. Technol. Mark. Complex. 2021, 7, 142. https://doi.org/ 10.3390/joitmc7020142

Received: 13 February 2021

Accepted: 21 May 2021

Published: 25 May 2021

Publisher's Note: MDPI stays neutral with regard to jurisdictional claims in published maps and institutional affiliations.

Copyright: (c) 2021 by the authors. Licensee MDPI, Basel, Switzerland. This article is an open access article distributed under the terms and conditions of the Creative Commons Attribution (CC BY) license (https:// creativecommons.org/licenses/by/ $4.0 /)$.

\begin{abstract}
Augmented reality (AR) technology is a computer-generated object that allows users to enrich the experience of products virtually with graphics, images, etc. Due to a lack of studies in developing countries like Malaysia, more studies are necessary to understand the pressing factors of diffusing AR technology for the flourishing retail industry. This research aimed to explore the factors affecting the adoption of AR technology in the retail sector through an extension of the technology acceptance model (TAM). The conceptual model was developed based on additional open-innovation-related constructs to the existing TAM constructs. To test the model, data were collected from 233 retail stores in Malaysia using a structured questionnaire survey. The PLS-based structural equation modeling technique was used to analyze the data. The empirical results confirmed that, except for external support and trading partner pressure, other factors, including perceived usefulness, attitude, competitive pressure, customer pressure, perceived cost, and technological knowledge have significant influences on the intention to use AR technology in retail stores. The attitude mediates the relationship between perceived usefulness and behavioral intention and the relationship between self-efficacy and behavioral intention. As operating cost was a critical factor, managers are advised to deliver various packages of after-sales services and free installation charges to curb expenses. This study improved TAM by offering a comprehensive model with cognitive and open innovation factors and provided suggestions for retail stores when they attempt to adopt AR technology to develop an open business model.
\end{abstract}

Keywords: augmented reality; retail industry; technology acceptance model; open innovation; Malaysia

\section{Introduction}

Augmented Reality (AR) integrates computer-generated objects, including video overlays or picture images, in the real world using technological appliances, e.g., eyeglasses, desktops, and smartphones [1,2]. AR technology allows users to use it in the virtual and real-world at the same time. AR technology enriches our experiences by including virtual mechanisms such as graphics, digital images, or sensations as a novel of interaction with the real world [3]. Considering the tremendous potential of AR technology, several businesses begin to adopt AR technology to interact with their customers. AR can help marketers promoting their products more creatively [3].

Coyne [4], a senior research analyst at Jones Lang Lasalle IP, Inc (JLL, Bogata, Colombia), has addressed that AR technology has an absolute potential in the retail sector, whereby AR technology provides a new level of interaction opportunities between product and consumer. AR technology can create a try-on experience, which the consumer can 
do at physical stores, to convince online buyers to purchase more products. Consumers are allowed to test and view products virtually through their smartphone cameras. Most contemporary apparel, home goods, spectacle, and cosmetic retailers use AR technology to market their products. Sephora is a cosmetic company using the Virtual Artist augmented reality app, allowing consumers to apply makeup virtually and learn techniques without going to the shopping mall. Retailers of home and furniture (such as IKEA) also use an AR app. The AR app in IKEA permits buyers to imagine how the furniture would look in their homes [5]. Topology Eyewear company allows its customers to try glasses virtually as it is only possible at physical stores. Markets and Markets [6] highlighted that the total value of augmented reality in the retail sector was USD 411.3 million, and by 2023, it is expected to reach USD 7951.2 million, with an expected cumulative annual growth (CAGR) of $47.1 \%$. When planning the marketing for businesses, it is important to think about AR technology usage. Since customers are now demanding sophisticated technology during their buying process, it is now time for retailers in Malaysia to think smartly and to develop open innovation-based business models [7] through adopting AR technology into their retail business.

Although AR technology's benefits and its relevance in doing business are not deniable, research shows that Malaysians are slow in adopting new technology [3]. Retail, tourism, gaming, and other sectors are slowly adopting AR technology [2]. Most marketing and entertainment fields in Malaysia are applying AR technology. Malaysian branches of some international companies are using AR technology as a marketing tool. In both products and services, Malaysian companies use AR technology as their marketing tool [3]; however, Malaysian societies are slower in adopting new technologies [8]. Therefore, AR technology usage in retail sectors is much smaller. Malaysian industries have to accept AR technology, which is part of nine pillars of the Fourth Industrial Revolution; otherwise, the Malaysian economy will lower their economic development. However, only $44 \%$ of Malaysians are aware that AR technology exists in Malaysia [9].

There have been considerable studies on AR adoption in various sectors like sports [10], computer games [11,12], and education [13]. These studies are mostly based on the developed countries such as the US [10,14], UK [15], Spain [13], and Germany [16]. Only a few studies [17-20] on developing countries and the retail store context are available. Perannagari et al. [17], in their thematic analysis, examined the factor of behavioral intention and identified eight themes: augmentation quality, media characteristics, value, flow concept, psychological factors, use motivation, etc. Fan [18] investigated adoption factors like environmental embedding, simulated physical control, cognitive fluency, cognitive load, product attitude, and product type as moderation. However, these studies fail to address external factors like external supports, competitor pressure, consumer pressure, and trading partner pressure. The studies missed the essentials of technological knowledge and cost as technology-specific factors. There is no indication about cognitive factors like self-efficacy and personal innovativeness in the forming of an attitude towards the AR use being established in past research in other fields. Therefore, more studies in developing countries like Malaysia must understand the pressing factors missing in existing literature regarding the diffusion of AR technology in the retail sector. Additionally, the existing research ignored complex relationships like mediation or moderation. With the mediation and moderation analysis, we could deep dig into the matter and bring out the problem with a better solution. As an online retail store is a new business pattern that falls under the category of small and medium enterprises, more research on the complex relationship could facilitate the adoption of new technologies.

Existing adoption research worked with various models such as the technology readiness and acceptance model (TRAM) [10], expectation confirmation theory (ECT) [11], uses and gratification theory (UGT) [16], and technology acceptance model (TAM) [15,20]. TAM is considered a widely used theory in the acceptance of various technologies [21,22]. TAM does not provide consistent results with lower explanatory power on many occa- 
sions $[23,24]$. Hence, an extended TAM might be able to explain why and how Malaysian people adopt AR in the retail sector.

The current research aimed to determine the factors affecting AR's behavioral intention in the retail sector in Malaysia. A comprehensive model by adding open innovation-related elements to TAM's original constructs is proposed to explain the influences of individual cognitive, technology-specific, and external contextual factors on the acceptance of AR in the retail industry. The other objective was to determine the moderating relationship of technological knowledge and the mediating relationship of attitude between perceived ease of use, usefulness, self-efficacy, and intention to use AR in the retail business. Thus, the present study aimed to fill the gap of looking at the behavioral intention through a direct, indirect, and versatile lens so that the diffusion of AR in Malaysia is made possible.

The rest of the paper is organized as follows. Section 2 presents the theoretical background and justification of the TAM extension. Section 3 discusses the conceptual model and constructs development, followed by the research design and sample in Section 4. Section 5 addresses the analysis of data, and Section 6 is the discussion. The paper concludes with major policy consequences, limitations, and suggestions for future studies in Section 7.

\section{Theoretical Background}

Acceptance of augmented reality is considered information and communication technology adoption. Many theories have been used in technology adoption research. The most common theories that are used for technology adoption are the theory of reasoned action (TRA) [25], theory of planned behavior (TPB) [26], Diffusion of Innovation (DOI) [27], technology acceptance model (TAM) [28,29], unified theory of acceptance and use of technology [30], the DeLone and McLean model of information success [31], and Bailey and Pearson's analysis of computer user satisfaction [32].

The technology acceptance model (TAM) is most widely used for information system research [21,22]. TAM was developed based on Fishbein and Ajzen's theory of reasoned action (TRA), rooted in social psychology [25]. Researchers in different areas have been using the TRA model widely, whereas TAM was introduced at the time of Davis's information system [28]. TAM consists of three constructs: attitude toward the system, perceived ease of use (PEU), and perceived usefulness (PU) that explain the user's motivation to adopt new technology. Later, Davis et al. [29] included behavioral intention (BI) in TAM as a new construct, directly affected by attitude and perceived usefulness. Legris et al. [24] also highlighted that TAM explains between $30 \%$ to $40 \%$ of system uses. Moreover, several researchers found PU to be the strongest construct in the model $[24,33]$. Therefore, the TAM model was employed in this research.

Although TAM is commonly used in information system research, some limitations have been found. For example, TAM contains some restricted factors that cannot handle new solutions or services [34]. Garaca [35] stated a limited possibility of prediction and explanation and a lack of practical value. Other research opined that an empirical study using TAM does not produce clear or consistent results; thus, it is important to identify additional constructs that need to be included in the model [24]. Tarhini et al. [23] argued that additional constructs for TAM might increase the explanatory power. This justification indicates the importance of the extension of the TAM model with other context-specific constructs.

\section{Conceptual Model and Constructs Development}

This study's conceptual model is based on TAM with additional constructs, including self-efficacy, personal innovativeness, perceived cost, technological knowledge, customer pressure, competitive pressure, trade partner pressure, external support, and competitor pressure, as shown in Figure 1.

Yun et al. [7] proposed four open innovation-based business models: customer open innovation, user open innovation, social entrepreneurship, and engineer open innovation. Therefore, in addition to including self-efficacy as an additional construct, this study 
considered some factors related to user open innovation, customer open innovation, and engineering open innovation concepts [7] in the extension of the TAM model. In the conceptual model, as shown in Figure 1, personal innovativeness, trading partner pressure, and competitive pressure are related to user open innovation; perceived usefulness, perceived ease of use, and customer pressure are related to customer open innovation; external support and technological knowledge are related to engineer open innovation.

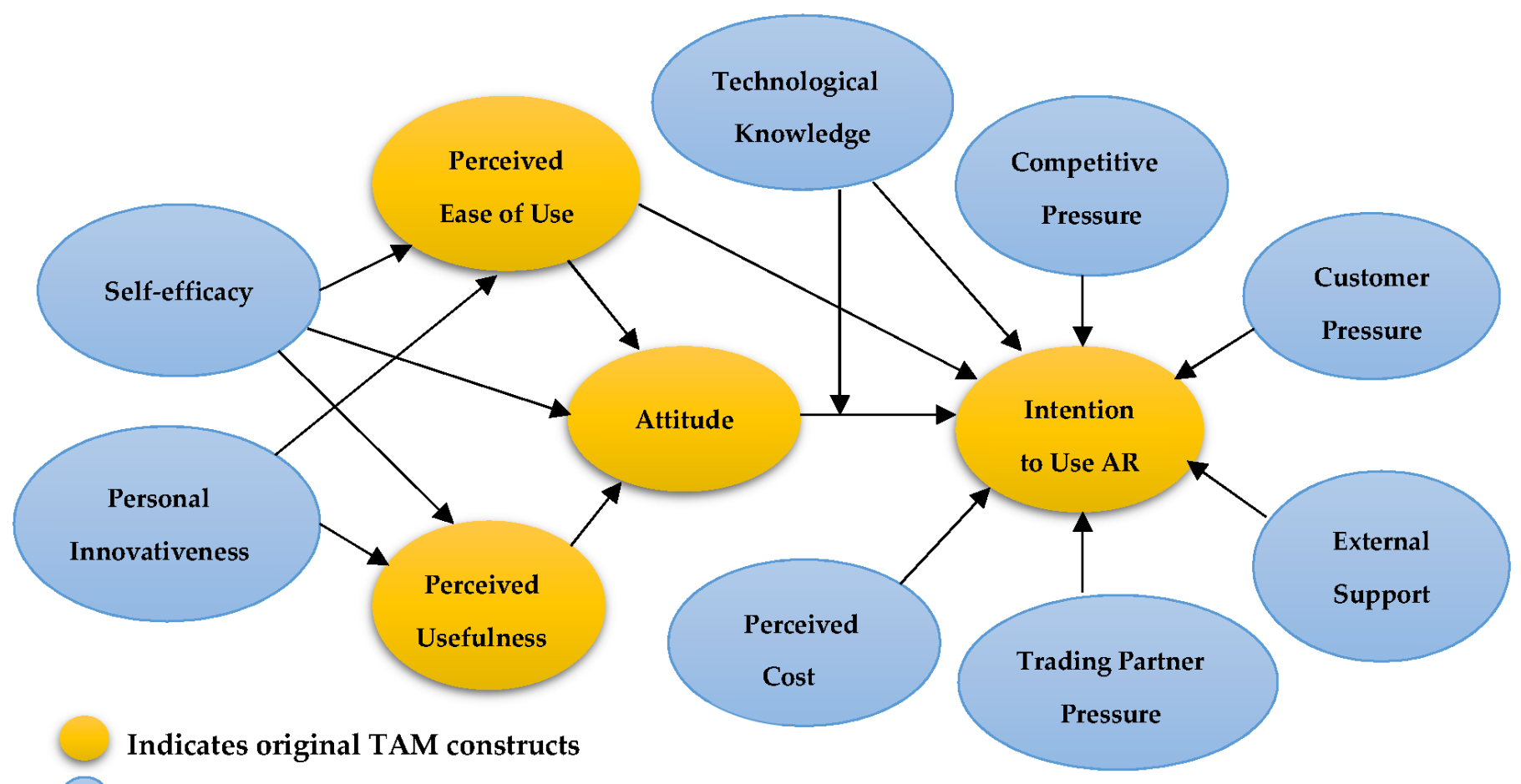

Indicates new constructs

Figure 1. Conceptual model.

\subsection{Self-Efficacy}

Self-efficacy refers to one's motivation and ability to perform specific tasks [36], which is adapted by Compeau and Higgins [37] after the first introduction in social cognitive theory [38]. Information system researchers [39-41] examined the relationship between computer self-efficacy and different types of tasks related to computers. Self-efficacy facilitates behavioral intention, the intention to act, and the development of action plans. However, to take an online course in practice, only usage intention is not enough; perceived capability is also needed to complete it. Numerous researchers confirmed the influence of self-efficacy on behavioral intention, and others identified the relationship of self-efficacy with attitude [42] as well as perceived ease of use and perceived usefulness [37,43]. Therefore, the following hypotheses are proposed.

Hypothesis 1 (H1). There is a significant association between self-efficacy and perceived ease of use.

Hypothesis 2 (H2). There is a significant association between self-efficacy and perceived usefulness.

Hypothesis 3 (H3). There is a significant association between self-efficacy and attitude.

\subsection{Personal Innovativeness}

Personal innovativeness is a consumer perspective external variable, an individual willing to try out innovation [44]. Those who have high innovativeness are more inclined to accept new technology $[20,45]$. Numerous researchers used the perceived innovativeness 
construct in the analysis of internet and mobile banking adoption [46], mobile services usage [47,48], mobile payment [49], and wireless Internet services [50]. Likewise, personal innovativeness has a significant positive effect on perceived ease of use and perceived usefulness [48,51]. Consumers perceive augmented reality as the latest innovation that might adopt and implement at a very early stage. Hence, it is justified to examine personal innovativeness as a determinant of behavioral intention. The following hypotheses are proposed.

Hypothesis 4 (H4). Personal innovativeness has a significant effect on perceived ease of use.

Hypothesis 5 (H5). Personal innovativeness has a significant effect on perceived usefulness.

\subsection{Perceived Ease of Use}

Perceived ease of use is considered the degree to which the consumers perceive new services or products as superior to their substitutes [27]. Adopting new technology towards its usefulness depends on the perceived ease of use [52,53]. Ha and Stoel's [53] study results revealed similar findings on online learning system usage intention. Researchers found that perceived ease of use has a significant positive effect on attitude [53-55]. Another study stated that consumers' attitudes towards technology usage directly affect the perceived ease of use [52]. Users find technology easy to use when they identify that the technology can be used without difficulties. So the users use that technology regularly. Past studies indicated that perceived ease of use has a significant direct or indirect positive effect on usage intention [56-58]. A person accepts any technology when they find it easy to use; on the other hand, complexity lowers the usage intention [59]. Therefore, the following hypotheses are proposed.

Hypothesis 6 (H6). There is a significant relationship between perceived ease of use and perceived usefulness.

Hypothesis 7 (H7). There is a significant relationship between perceived ease of use and attitude.

Hypothesis $\mathbf{8} \mathbf{( H 8 )}$. There is a significant relationship between perceived ease of use and behavioral intention.

\subsection{Perceived Usefulness}

Various research contexts identified that perceived usefulness has a significant influence on behavioral intention in regard to new technology adoption, such as virtual reality [60], mobile exergames [61], and mobile applications [62]. Sumak et al. [63] confirmed that perceived usefulness has a significant positive influence on attitude. Researchers identified perceived usefulness as one of the most influential predictors in explaining and predicting users' information technology acceptance intention $[22,64,65]$. When users perceive that information technology is beneficial to their business, this positive perception will motivate them to adopt the information technology. Therefore, the following hypotheses are proposed.

Hypothesis 9 (H9). There is a significant relationship between perceived usefulness and attitude.

Hypothesis 10 (H10). There is a significant relationship between perceived usefulness and behavioral intention.

\subsection{Attitude}

Ajzen [26] argued that attitude has a significant influence on behavioral intention. Yadav and Pathak [66] conducted a study in India and confirmed that attitude positively affects behavioral intention. Numerous studies show a significant positive relationship 
between attitude and buying intention [67]. When consumers had great intentions to use technology, they would have a positive attitude towards the system [68]. Therefore, the following hypothesis is proposed.

Hypothesis 11 (H11). There is a significant relationship between attitude and behavioral intention.

\subsection{Perceived Cost}

Cost is one of the most important factors affecting technology adoption $[69,70]$. The cost of developing a program for AR, maintenance, and upgrade of websites, and the availability of the services to consumers are the main costs incurred for web-based activities [71]. High cost involves technology implementation since small businesses are reluctant to use IT-based programs [72]. Although high costs are involved in implementing IT, firms without the latest technology are left far behind their competitors in this digital era. It could be hypothesized that cost negatively influences AR adoption. Therefore, the following hypothesis is proposed.

Hypothesis 12 (H12). Perceived cost has a significant negative effect on AR technology adoption intention.

\subsection{Competitor, Trading Partner, and Customer Pressure}

Companies accept new technology when they find that other competitors are using the same technology [73,74]. A study conducted by Matikiti et al. [75] found that external pressure significantly influences new technology adoption intention. Sharma et al. [76] stated that trading partners' pressure is one of the dominant factors affecting innovation adoption. Firms might adopt specific innovation if pressure comes from powerful partners who mostly contribute to their profitability [77]. To and Ngai [78] found that a firm adopts innovation if dominant suppliers have already adopted that technology earlier. Hasani et al. [79] defined "customer pressure" as the customer demands and behaviors that drive businesses to adopt new technologies. Customer pressure is the driving force behind the focal firm's adoption of ISO standards; consequently, it positively correlates with quality control performance [80]. Thus, there is a significant positive correlation between "customer pressure" and the intention of SMEs to adopt new technologies [81]. It also has a significant impact on the adoption of green innovations by SMEs [82-84]. Therefore, the following hypotheses are proposed.

Hypothesis 13 (H13). Pressure from competitors significantly affects the AR adoption intention.

Hypothesis 14 (H14). Pressure from customers significantly affects AR adoption intention.

Hypothesis 15 (H15). Pressure from trading partners has a significant effect on AR adoption intention.

\subsection{External Support}

External support is considered the support that comes from outside the firm, and it influences the firms' decision-making process, precisely, when the company accepts new technology [77]. Wu and Subramaniam [85] stated that the greater possibility of accepting new technology happens when support comes from an external body. Expertise comes from a third party; a suitable policy of standard and powerful partners are the main body providing external support $[27,76]$. Therefore, the following hypothesis is proposed.

Hypothesis 16 (H16). External support has a significant positive effect on AR adoption intention.

\subsection{Technological Knowledge}

Researchers identified the lack of primary expertise hindering the adoption and diffusion of information technology [86,87]. Companies usually go through knowledge 
gain approaches before making final decisions and finding alternatives to adopt new technology [88]. Berg and Lingen [88] addressed that knowledge discovery is important as it will create awareness of identifying opportunities and the barriers and challenges faced during the adoption process. Once decision-makers have gained knowledge about the new technology, they will add value to adopting the new technology. So it can be concluded that technological knowledge has a significant effect on adopting innovative technology. Therefore, the following hypothesis is proposed.

Hypothesis 17 (H17). There is a significant relationship between technological knowledge and behavioral intention of AR technology usage.

\subsection{The Moderating Role of Technological Knowledge}

Online retailers are operating businesses in a knowledge-based society, and, therefore, technology knowledge is essential for them to improve their competitiveness. Technological knowledge enables retailers to develop a positive attitude and ultimately results in an increased intention to use the technology. The researcher identified technological knowledge moderating the association between attitude toward technology usage and behavioral intention [75]. El-Gohary [73] found that a lack of technical knowledge inhibits e-commerce adoption among SMEs. According to Lichtenthaler [89], knowledge is central to accepting innovative technology. There is a dearth of research examining the moderating effect of technology knowledge. Yaqub et al. [90] stated that low adoption of online payment is due to the lack of awareness of technological knowledge of the system. In this research, the researchers argued that the knowledge of technology of managers strengthened the positive relationship between attitude and behavioral intention. This effect may be larger for managers with greater technological knowledge because greater knowledge could lead them to trust the technology more, and, as a consequence, the positive effect of attitude on behavior could be reinforced. Therefore, this study examined the effect of technological knowledge on the moderating effect of the attitude-intention relationship. This indicated that higher technological knowledge could reduce the gap between the attitude and intention to use the technology.

Therefore, this study also hypothesizes that:

Hypothesis 18 (H18). Technological knowledge moderates the relationship between attitude towards AR usage and behavioral intention.

\subsection{Mediating Effect of Attitude}

Venkatesh et al. [91] argued that attitude mediates the relationship between perceived usefulness and behavioral intention. In the technology acceptance literature, Schaper and Pervan [92] also confirmed this relationship in their research on the healthcare domain. Gajanayake et al. [93] found that attitude partially mediates the relationship between perceived usefulness and behavioral intention. Krishnan et al. [94] suggested that attitude mediates the relationship between perceived ease of use, perceived usefulness, and behavioral intention. Therefore, the following hypotheses are proposed.

Hypothesis 19 (H19). Attitude mediates the relationship between perceived ease of use and behavioral intention.

Hypothesis 20 (H20). Attitude mediates the relationship between perceived usefulness and behavioral intention.

Hypothesis 21 (H21). Attitude mediates the relationship between self-efficacy and behavioral intention. 


\section{Research Design and Sample}

A cross-sectional survey method was used to collect data from 233 retailer businesses in Malaysia with our colleagues' and students' help. The respondents in this study were the owners or managers of retail businesses. An online-based survey was used to confirm the respondents' anonymity and increase their responses [95]. To reduce the chances of missing responses, an online questionnaire was developed in a way that respondents have to answer all questions. Regarding sample size adequacy, the current study adopted the $\mathrm{G}^{*}$ power program priori test. As set out in Cohen's proposal [96], the suggested samples were 178 for eleven independent constructions or predictors ( $\mathrm{F} 2=0.15$ for effect size, $\alpha=0.05$ for error type one, $\beta=0.20$ for error type two).

\subsection{Measurement}

Self-efficacy was measured from Chao's [97] study. Perceived ease of use was measured from Alam et al. [98] and Huang and Liao's [99] study. Technology knowledge was measured using items from Berg and Lingen's [88] study. In this research, the customer pressure scale was measured from Wanyoike et al. [74] and Zhu and Kraemer's [100] studies. Personal innovativeness and perceived usefulness were measured by the scale developed by Janssen [101]. Competitor pressure was measured based on the studies of Salwani et al. [102] and Wanyoike et al. [74]. Attitude and behavioral intention scales were developed based on Alam et al. [98] and Alam and Sayuti [103]. The cost was measured based on the study of Alam et al. [70]. The construct trading partners' pressure and external support were measured from the study of Paydar et al. [77]. All items in this research were modified to suit this research, as illustrated in Appendix A. This study's variables were measured using a 5 -point Likert scale ranging from $1=$ strongly disagree to $5=$ strongly agree. All the constructs of this study were operationalized as reflective constructs.

\subsection{Common Method Bias}

According to Podsakoff et al. [104], few techniques are used to test common method variances, such as Harman's one-factor test, the respondents' confidentiality, clarity of items or questions, and wording questions in reverse. In this study, we used Harman's [105] common method bias by employing an exploratory factor analysis. To assess the sampling adequacy for the factor analysis KMO (Kaiser-Meyer-Olkin) was used, and the results showed that all the values were above 0.5 in the diagonal of the matrix and the KMO coefficient value was 0.819 . An un-rotated factor analysis technique was used and found that all factors loaded separately, and no single factor accounted for more than $50 \%$. These results indicated that there were eleven factors loaded with eigenvalues more than one, and the first factor explained about $23.7 \%$, and, thus, we could conclude that common method bias was not the issue in this research. The studies [104,106] argued that a common method bias exists if there is a single factor that explains variance more than $50 \%$.

\section{Analysis of the Data}

The model proposed in this study was tested using Smart-PLS-3 software. Variancebased PLS-SEM (partial least square structural equation modeling) technique was employed in the present study to test the hypotheses. According to Ringle et al. [107], SmartPLS path-modeling technique has been widely used to show direct and indirect connections in casual relationships. PLS-SEM works better than the CB-based SEM in regard to using interactional variables as a moderator in the complex model with larger constructs and items running within a relatively moderate sample size [106]. Recently, PLS-SEM has gained massive attention from different research fields, including marketing, strategic management, operations management, and human resource management [108]. A two-step approach was used to test the model: (a) measurement model or inner model and (b) structural or outer models [109]. To measure the model, we examined the construct's reliability and validity, and the structural model determined the path coefficient and their significance. 


\subsection{Measurement Model Analysis}

Before testing the proposed hypotheses, the measurement model was tested. Figure 2 shows the measurement model for this study. Table 1 shows the outer loading, Cronbach's alpha, composite reliability values, and average variance extracted (AVE).

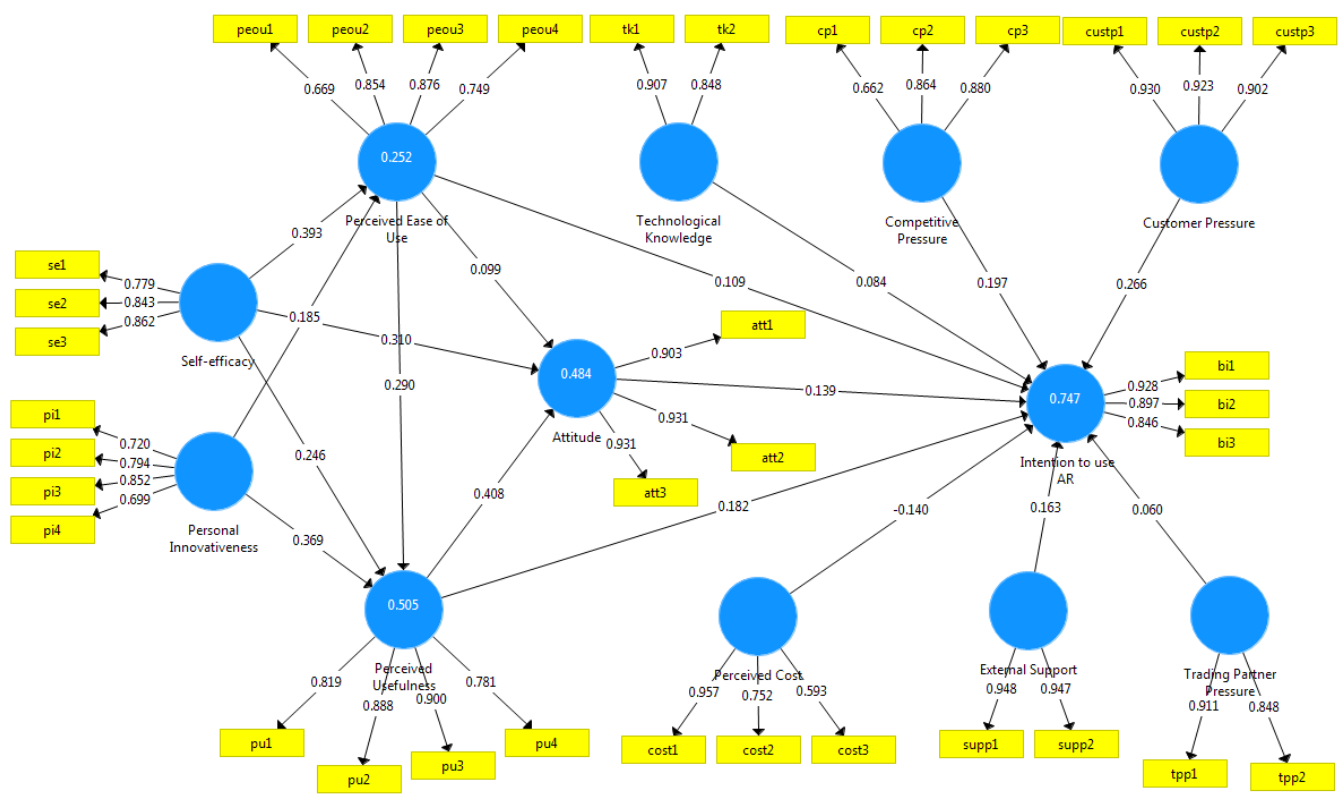

Figure 2. Measurement model.

Table 1. Factor loadings and reliability statistics.

\begin{tabular}{|c|c|c|c|c|c|c|}
\hline Constructs & Items & Loadings & AVE & Composite Reliability & Cronbach's Alpha & Rho_A \\
\hline \multirow{3}{*}{ Attitude } & att1 & 0.903 & \multirow{3}{*}{0.850} & \multirow{3}{*}{0.944} & \multirow{3}{*}{0.911} & \multirow{3}{*}{0.912} \\
\hline & att2 & 0.931 & & & & \\
\hline & att3 & 0.931 & & & & \\
\hline \multirow{3}{*}{ Behavioral Intention } & bi1 & 0.928 & \multirow{3}{*}{0.794} & \multirow{3}{*}{0.920} & \multirow{3}{*}{0.869} & \multirow{3}{*}{0.873} \\
\hline & bi2 & 0.897 & & & & \\
\hline & bi3 & 0.846 & & & & \\
\hline \multirow{3}{*}{ Competitor Pressure } & cp1 & 0.762 & \multirow{3}{*}{0.653} & \multirow{3}{*}{0.848} & \multirow{3}{*}{0.738} & \multirow{3}{*}{0.804} \\
\hline & cp2 & 0.864 & & & & \\
\hline & cp3 & 0.880 & & & & \\
\hline \multirow{3}{*}{ Customer Pressure } & custp1 & 0.930 & \multirow{3}{*}{0.844} & \multirow{3}{*}{0.942} & \multirow{3}{*}{0.907} & \multirow{3}{*}{0.909} \\
\hline & custp2 & 0.923 & & & & \\
\hline & custp3 & 0.902 & & & & \\
\hline \multirow{3}{*}{ Perceived Cost } & pc1 & 0.957 & \multirow{3}{*}{0.611} & \multirow{3}{*}{0.820} & \multirow{3}{*}{0.761} & \multirow{3}{*}{1.129} \\
\hline & pc2 & 0.752 & & & & \\
\hline & pc3 & 0.793 & & & & \\
\hline \multirow{4}{*}{ Perceived Ease of Use } & peou1 & 0.769 & \multirow{4}{*}{0.626} & \multirow{4}{*}{0.869} & \multirow{4}{*}{0.799} & \multirow{4}{*}{0.830} \\
\hline & peou2 & 0.854 & & & & \\
\hline & peou3 & 0.876 & & & & \\
\hline & peou4 & 0.749 & & & & \\
\hline
\end{tabular}


Table 1. Cont.

\begin{tabular}{|c|c|c|c|c|c|c|}
\hline Constructs & Items & Loadings & AVE & Composite Reliability & Cronbach's Alpha & Rho_A \\
\hline \multirow{4}{*}{ Personal Innovativeness } & pi1 & 0.720 & \multirow{4}{*}{0.590} & \multirow{4}{*}{0.851} & \multirow{4}{*}{0.774} & \multirow{4}{*}{0.790} \\
\hline & pi2 & 0.794 & & & & \\
\hline & pi3 & 0.852 & & & & \\
\hline & pi4 & 0.799 & & & & \\
\hline \multirow{4}{*}{ Perceived Usefulness } & pu1 & 0.819 & \multirow{4}{*}{0.720} & \multirow{4}{*}{0.911} & \multirow{4}{*}{0.870} & \multirow{4}{*}{0.879} \\
\hline & pu2 & 0.888 & & & & \\
\hline & pu3 & 0.900 & & & & \\
\hline & pu4 & 0.781 & & & & \\
\hline \multirow{3}{*}{ Self-efficacy } & se1 & 0.779 & \multirow{3}{*}{0.687} & \multirow{3}{*}{0.868} & \multirow{3}{*}{0.774} & \multirow{3}{*}{0.795} \\
\hline & se2 & 0.843 & & & & \\
\hline & se3 & 0.862 & & & & \\
\hline \multirow{2}{*}{ External Support } & es1 & 0.948 & \multirow{2}{*}{0.898} & \multirow{2}{*}{0.946} & \multirow{2}{*}{0.886} & \multirow{2}{*}{0.886} \\
\hline & es2 & 0.947 & & & & \\
\hline \multirow{2}{*}{ Trading Partner Pressure } & tp1 & 0.911 & \multirow{2}{*}{0.774} & \multirow{2}{*}{0.873} & \multirow{2}{*}{0.713} & \multirow{2}{*}{0.744} \\
\hline & tp2 & 0.848 & & & & \\
\hline \multirow{2}{*}{ Technological Knowledge } & tk1 & 0.907 & \multirow{2}{*}{0.771} & \multirow{2}{*}{0.870} & \multirow{2}{*}{0.706} & \multirow{2}{*}{0.732} \\
\hline & tk2 & 0.848 & & & & \\
\hline
\end{tabular}

\subsection{Convergent Validity}

High factor loading of measured items means that the construct converges on a common point. The rule of thumb is that the factor loading should be 0.70 or more in PLS analysis [110]. This study's result revealed that all factor loading values were more than 0.70 (ranging from 0.720 to 0.957 ), which exceeded the recommended threshold value of 0.5 [111], and verified the convergence validity [112,113]. This study further tested convergent validity by assessing AVE. Hair et al. [108] argued that it is good if the AVE value is 0.50 or higher. The AVE value was found to be between 0.597 and 0.898 , which is higher than the threshold value of 0.50 . Therefore, we can conclude that there was a convergent validity of the scale.

\subsection{Reliability}

Reliability was tested by assessing Cronbach's alpha and composite reliability value. Cronbach's alpha value ranged from 0.706 to 0.911 (see Table 1), and the value of composite reliability ranged from 0.820 to 0.946 , which are greater than the threshold value of 0.7 [111]. Hence, it demonstrated a satisfactory level of reliability.

\subsection{Discriminant Validity}

Discriminant validity was assessed by examining both the Fornell-Larcker criterion and the Heterotrait-Monotrait ratio (HTMT) approach. To determine the discriminant validity of the Fornell-Larcker approach [114], the square root of each construct's AVE value should be greater than its highest correlation with any other construct of a model [111]. This study confirms the rules (Table 2). According to Henseler et al. [115], the FornellLarcker criterion cannot reliably detect a common research situation's lack of discriminant validity. Therefore, these researchers suggested examining the discriminant validity by testing HTMT. Thus, in this research, HTMT was also used to test the discriminant validity, and the results of this test are shown in Table 3. According to Kline [116], if the HTMT value is greater than the threshold value of 0.90 , or, in the case of a conservative approach, the value is higher than 0.85 , it suggests a lack of discriminant validity $[111,115]$. The study 
results complied with the standard suggested (Table 3). Overall, these analyses suggested a satisfactory discriminant validity.

Table 2. Fornell-Larcker correlation matrix.

\begin{tabular}{|c|c|c|c|c|c|c|c|c|c|c|c|c|}
\hline & ATT & BI & $\mathrm{CP}$ & CUSP & ES & PC & PEOU & PI & PU & SE & TK & TP \\
\hline ATT & 0.922 & & & & & & & & & & & \\
\hline BI & 0.640 & 0.891 & & & & & & & & & & \\
\hline $\mathrm{CP}$ & 0.448 & 0.607 & 0.808 & & & & & & & & & \\
\hline CUSP & 0.587 & 0.774 & 0.532 & 0.919 & & & & & & & & \\
\hline ES & 0.521 & 0.718 & 0.481 & 0.881 & 0.948 & & & & & & & \\
\hline PC & 0.479 & 0.350 & 0.399 & 0.368 & 0.351 & 0.782 & & & & & & \\
\hline PEOU & 0.466 & 0.528 & 0.361 & 0.430 & 0.368 & 0.304 & 0.791 & & & & & \\
\hline PI & 0.493 & 0.570 & 0.382 & 0.478 & 0.486 & 0.501 & 0.358 & 0.768 & & & & \\
\hline PU & 0.631 & 0.709 & 0.471 & 0.625 & 0.567 & 0.461 & 0.539 & 0.581 & 0.849 & & & \\
\hline SE & 0.580 & 0.662 & 0.442 & 0.626 & 0.606 & 0.366 & 0.474 & 0.441 & 0.547 & 0.829 & & \\
\hline TK & 0.499 & 0.538 & 0.423 & 0.490 & 0.397 & 0.448 & 0.370 & 0.337 & 0.553 & 0.478 & 0.878 & \\
\hline TP & 0.506 & 0.527 & 0.369 & 0.436 & 0.421 & 0.570 & 0.354 & 0.517 & 0.774 & 0.443 & 0.460 & 0.880 \\
\hline
\end{tabular}

Note: ATT = Attitude, BI = Behavioral Intention, CP = Competitive Pressure, CUST = Customer Pressure, ES $=$ External Support, PC $=$ Perceived Cost, PEOU $=$ Perceived Ease of Use, PI $=$ Personal Innovativeness, $\mathrm{PU}=$ Perceived Usefulness, $\mathrm{SE}=$ Self-efficacy, $\mathrm{TK}=$ Technology Knowledge, TP $=$ Trading Partner Pressure .

Table 3. Heterotrait-Monotrait ratio (HTMT) approach.

\begin{tabular}{|c|c|c|c|c|c|c|c|c|c|c|c|c|}
\hline & Att & BI & $\mathrm{CP}$ & Custp & ES & PC & PEOU & PI & PU & SE & TK & TP \\
\hline \multicolumn{13}{|l|}{ Att } \\
\hline BI & 0.717 & & & & & & & & & & & \\
\hline $\mathrm{CP}$ & 0.530 & 0.727 & & & & & & & & & & \\
\hline Custp & 0.645 & 0.872 & 0.621 & & & & & & & & & \\
\hline ES & 0.579 & 0.820 & 0.573 & 0.780 & & & & & & & & \\
\hline PC & 0.489 & 0.281 & 0.418 & 0.346 & 0.360 & & & & & & & \\
\hline PEOU & 0.548 & 0.623 & 0.450 & 0.494 & 0.426 & 0.295 & & & & & & \\
\hline PI & 0.546 & 0.664 & 0.460 & 0.539 & 0.561 & 0.586 & 0.411 & & & & & \\
\hline PU & 0.705 & 0.809 & 0.558 & 0.698 & 0.641 & 0.417 & 0.621 & 0.672 & & & & \\
\hline SE & 0.682 & 0.806 & 0.559 & 0.742 & 0.728 & 0.398 & 0.581 & 0.544 & 0.653 & & & \\
\hline TK & 0.615 & 0.679 & 0.550 & 0.601 & 0.487 & 0.458 & 0.480 & 0.398 & 0.706 & 0.641 & & \\
\hline TP & 0.627 & 0.655 & 0.496 & 0.534 & 0.525 & 0.657 & 0.462 & 0.673 & 0.788 & 0.598 & 0.656 & \\
\hline
\end{tabular}

\subsection{Testing Multicollinearity}

As suggested by Kleinbaum et al. [117], one significant technique, including the evaluation of Variance Inflation Factor (VIF), was used to decide the presence of multicollinearity among independent variables in this research. The regression analysis outcome showed that VIF ranged from 1.107 to 1.682 , which indicated well below 10. This concluded that multicollinearity was not the issue in this research.

\subsection{Coefficient of Determination}

Santosa et al. [118] proposed a need to measure the models' explanatory powers by ascertaining the endogenous variable's coefficient of determination $\left(R^{2}\right)$. Falk and Miller [119] suggested that the $R^{2}$ of the endogenous variable ought to be 0.10 . Cohen [96] 
recommended, based on different researchers, that the value of $\mathrm{R}^{2}$ of endogenous constructs is significant when the value is 0.26 , followed by the value of 0.13 , which is considered moderate; lastly, if the value is 0.02 , it is deemed to be weak. In Table 4 , the $\mathrm{R}^{2}$ estimations of every endogenous value found in this research are over the PLS analysis prerequisites, as recommended by Falk and Miller [119]. $\mathrm{R}^{2}$ of this research was higher compared to the cut-off value, in this manner, demonstrating that the model fell into an acceptable level.

Table 4. VIF value, $R^{2}$, and $Q^{2}$.

\begin{tabular}{|c|c|c|c|c|c|c|}
\hline \multirow{2}{*}{ Constructs } & \multicolumn{4}{|c|}{ VIF } & \multirow{2}{*}{$\mathbf{R}^{2}$ (Endogenous Variables) } & \multirow{2}{*}{$\mathrm{Q}^{2}$ (Endogenous Variables) } \\
\hline & Att & BI & PEOU & PU & & \\
\hline Attitude & & 2.051 & & & 0.484 & 0.313 \\
\hline Behavioral Intention & & & & & 0.747 & 0.501 \\
\hline Competitor Pressure & & 1.563 & & & & \\
\hline Customer pressure & & 5.614 & & & & \\
\hline External Support & & 4.589 & & & & \\
\hline Perceived Cost & & 1.740 & & & & \\
\hline Perceived Ease of Use & 1.507 & 1.518 & & 1.337 & 0.252 & 0.126 \\
\hline $\begin{array}{c}\text { Personal } \\
\text { Innovativeness }\end{array}$ & & & 1.242 & 1.287 & & \\
\hline Perceived Usefulness & 1.666 & 4.156 & & & 0.505 & 0.411 \\
\hline Self-efficacy & 1.525 & & 1.242 & 1.448 & & \\
\hline $\begin{array}{l}\text { Technological } \\
\text { Knowledge }\end{array}$ & & 1.679 & & & & \\
\hline $\begin{array}{l}\text { Trading Partner } \\
\text { Pressure }\end{array}$ & & 3.061 & & & & \\
\hline
\end{tabular}

\subsection{Structural Model Analysis}

The structural model and the hypotheses of this research were evaluated by using the path coefficient and effect size $\left(\mathrm{f}^{2}\right)$ based on the recommendation of Hair et al. [111]. It employed 5000 bootstrap subsamples from 233 cases to analyze the significance of the findings. A 5 percent level of significance was considered in testing the proposed hypotheses and the structural model. The confidence interval report was further analyzed along with the $t$-values (1.65) and $p$-values (0.05) to test the hypothesized relationship's significance. Figure 3 shows the structural model of this research, and Table 5 shows the hypotheses results of this study.

To determine the model's predictive relevance, Stone-Geisser's $Q^{2}[120,121]$ was estimated. The $Q^{2}$ value was calculated by blindfolding and utilizing the Smart PLS package. The blindfolding procedure applied to endogenous latent variables only when the reflective measurement model specification and the single-item endogenous constructs were specified. "Having a $Q^{2}$ greater than zero for a specific target endogenous construct indicates that the predictive relevance for the model path for that specific latent variable" [104]. The model's results indicated that the cross-validated redundancy values for "behavioral intention", "perceived usefulness", "attitude", and "perceived ease of use" were, respectively, $0.505,0.401,0.313$, and 0.126 , which are all greater than zero, indicating that the employed model's predictive validity was achieved.

The PLS results (Table 5) showed the values of self-efficacy on perceived ease of use $($ Beta $=0.393 ; t=6.728 ; p=0.000)$, perceived usefulness $($ Beta $=0.246 ; t=4.744 ; p<0.01)$, and attitude (Beta $=0.310 ; t=4.764 ; p=0.000)$. Personal innovativeness significantly affected the perceived ease of use (Beta $=0.185 ; t=2.852 ; p<0.01$ ) and perceived usefulness (Beta $=0.369 ; t=6.243 ; p=0.000$ ). Perceived ease of use significantly influenced perceived 
usefulness (Beta $=0.290 ; t=5.802 ; p=0.000$ ), and behavioral intention (Beta $=0.109$; $t=2.330 ; p<0.05)$. Perceived usefulness was found to have a significant relationship with attitude (Beta $=0.408 ; t=5.778 ; p=0.000)$. However, the relationships of perceived ease of use (Beta $=0.099 ; t=1.557 ; p>0.05)$ on attitude showed insignificance. Therefore, we accepted H1, H2, H3, H4, H5, H6, H8, H9 but rejected H7.

Table 5. Structural model and hypothesis testing result.

\begin{tabular}{lcccccccc}
\hline \multicolumn{1}{c}{ Hypothesis } & STD Beta & STD Error & $t$-Values & $p$-Values & $\mathbf{2 . 5 \%}$ & $\mathbf{9 7 . 5 \%}$ & $\begin{array}{c}\text { Significance } \\
(\boldsymbol{p}<\mathbf{0 . 0 5 )}\end{array}$ & $f^{2}$ \\
\hline H1: SE -> PEOU & 0.393 & 0.058 & 6.728 & 0.000 & 0.273 & 0.501 & Supported & 0.166 \\
\hline H2: SE -> PU & 0.246 & 0.052 & 4.744 & 0.000 & 0.142 & 0.344 & Supported & 0.085 \\
\hline H3: SE -> ATT & 0.310 & 0.065 & 4.764 & 0.000 & 0.182 & 0.436 & Supported & 0.122 \\
\hline H4: PI -> PEOU & 0.185 & 0.065 & 2.852 & 0.004 & 0.068 & 0.325 & Supported & 0.037 \\
\hline H5: PI -> PU & 0.369 & 0.059 & 6.243 & 0.000 & 0.253 & 0.485 & Supported & 0.214 \\
\hline H6: PEOU -> PU & 0.290 & 0.050 & 5.802 & 0.000 & 0.192 & 0.387 & Supported & 0.127 \\
\hline H7: PEOU -> ATT & 0.099 & 0.064 & 1.557 & 0.119 & -0.027 & 0.223 & NS & 0.013 \\
\hline H8: PEOU -> BI & 0.109 & 0.047 & 2.330 & 0.020 & 0.022 & 0.207 & Supported & 0.033 \\
\hline H9: PU -> ATT & 0.408 & 0.071 & 5.778 & 0.000 & 0.262 & 0.536 & Supported & 0.194 \\
\hline H10: PU -> BI & 0.182 & 0.076 & 2.415 & 0.016 & 0.035 & 0.336 & Supported & 0.032 \\
\hline H11: ATT -> BI & 0.139 & 0.050 & 2.794 & 0.005 & 0.042 & 0.239 & Supported & 0.037 \\
\hline H12: PC -> BI & -0.140 & 0.043 & 3.290 & 0.001 & -0.217 & -0.049 & Supported & 0.044 \\
\hline H13: CP-> BI & 0.197 & 0.037 & 5.301 & 0.000 & 0.121 & 0.267 & Supported & 0.098 \\
\hline H14: CUSTP -> BI & 0.266 & 0.110 & 2.412 & 0.016 & 0.046 & 0.484 & Supported & 0.050 \\
\hline H15: TP -> BI & 0.060 & 0.061 & 0.996 & 0.319 & -0.065 & 0.176 & NS & 0.005 \\
\hline H16: ES -> BI & 0.163 & 0.093 & 1.749 & 0.080 & -0.016 & 0.354 & NS & 0.023 \\
\hline H17: TK -> BI & 0.084 & 0.038 & 2.206 & 0.027 & 0.008 & 0.158 & Supported & 0.016 \\
\hline
\end{tabular}

Note: $\mathrm{SE}=$ Self-efficacy, PEOU $=$ Perceived Ease of Use, $\mathrm{PU}=$ Perceived Usefulness, ATT $=$ Attitude, TP $=$ Trading Partner Pressure, PI $=$ Personal Innovativeness, $\mathrm{CP}=$ Competitive Pressure, CUSTP $=$ Customer Pressure, $\mathrm{PC}=$ Perceived Cost, TK $=$ Technological Knowledge, ES = External Support, BI = Behavioral Intention.

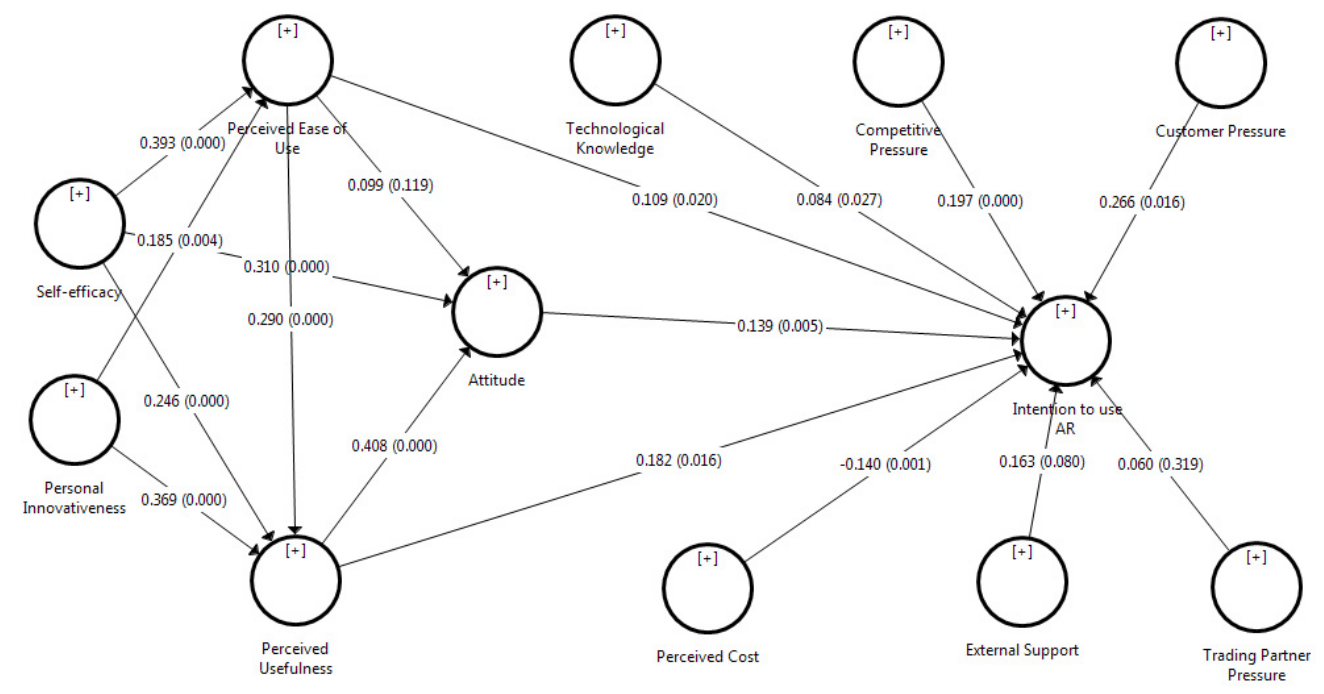

Figure 3. Structural model.

The outcome of PLS regression (Table 5) showed that the construct perceived usefulness $($ Beta $=0.182 ; t=2.415 ; p<0.05)$, attitude (Beta $=0.139 ; t=2.794 ; p=0.00)$, competitive 
pressure (Beta $=0.197 ; t=5.301 ; p=0.00)$, customer pressure (Beta $=0.266 ; t=2.412$; $p<0.05$ ), and technological knowledge (Beta $=0.084 ; t=2.206 ; p<0.05$ ) had a significantly positive effect on the behavioral intention to use AR. The effects of trading partner pressure (Beta $=0.060 ; t=0.996 ; p>0.05)$ and external support (Beta $=0.164 ; t=1.749 ; p>0.05)$ on behavioral intention to use AR in retail stores were not significant, while the perceived cost (Beta $=-0.140 ; t=3.290 ; p<0.01$ ) was found to have a negative but significant relationship with behavioral intention. Therefore, it concluded that hypotheses 10-14 and 17 were supported and 15, 16 were not supported according to the path coefficient results.

\subsection{Moderating Effect of Technology Knowledge}

Usually, the direct link between attitude and behavioral intentions remains quite strong; unfortunately, this study found a weaker relationship. Thus, this study added technological knowledge as the moderating variable to explore the reasoning within the indirect relationship. Study results (Table 6 and Figure 4) showed that technology knowledge does not moderate the relationship between attitude and behavioral intention (Beta $=0.041 ; t=1.059 ; p>0.05)$. Figure 5 also showed that the BI-ATT lines in three different TK levels have similar slopes. Thus, hypothesis 18 was rejected. This research result was inconsistent with Matikiti et al. [76].

Table 6. Testing results of moderation and mediation.

\begin{tabular}{lccccc}
\hline \multicolumn{1}{c}{ Hypothesis } & STD Beta & $\begin{array}{c}\text { Standard } \\
\text { Error }\end{array}$ & $t$-Values & $p$-Values & $\begin{array}{c}\text { Significance } \\
(p<0.05)\end{array}$ \\
\hline Moderation & & & 1.059 & $>0.05$ & $\begin{array}{c}\text { Not } \\
\text { Supported }\end{array}$ \\
\hline H18: TK*ATT -> BI & 0.041 & & & & \\
\hline Mediation & & 0.010 & 1.325 & 0.185 & $\begin{array}{c}\text { Not } \\
\text { Supported }\end{array}$ \\
\hline H19: PEOU -> ATT -> BI & 0.014 & 0.022 & 2.621 & 0.009 & Supported \\
\hline H20: PU -> ATT-> BI & 0.057 & 0.020 & 2.212 & 0.027 & Supported \\
\hline H21: SE -> ATT-> BI & 0.043 & & & &
\end{tabular}

In this study, the bootstrapping method was used to test the mediation effect of attitude on the relationship between perceived ease of use, perceived usefulness, and self-efficacy on behavioral intention based on Hair Jr. et al. [111], and Hayes and Preacher's [122] suggestion. It is unnecessary to assume the products' sampling distributions or the indirect effect of the bootstrapping method [122,123]. The mediating effect was tested with Smart PLS 3.0 for 233 cases and 5000 subsamples.

It was clear that attitude mediated the relationship between perceived usefulness and behavioral intention (Beta $=0.057, t$-value $=2.621, p$-value $=0.009$ ); and self-efficacy and behavioral intention (Beta $=0.043, t$-value $=2.212, p$-value $=0.027$ ). However, attitude did not mediate the association between perceived ease of use and behavioral intention $($ Beta $=0.014, t$-value $=1.325, p$-value $=0.185)$. Therefore, we accepted hypothesis 20 and hypothesis 21, and rejected hypothesis 19 (Table 6). 


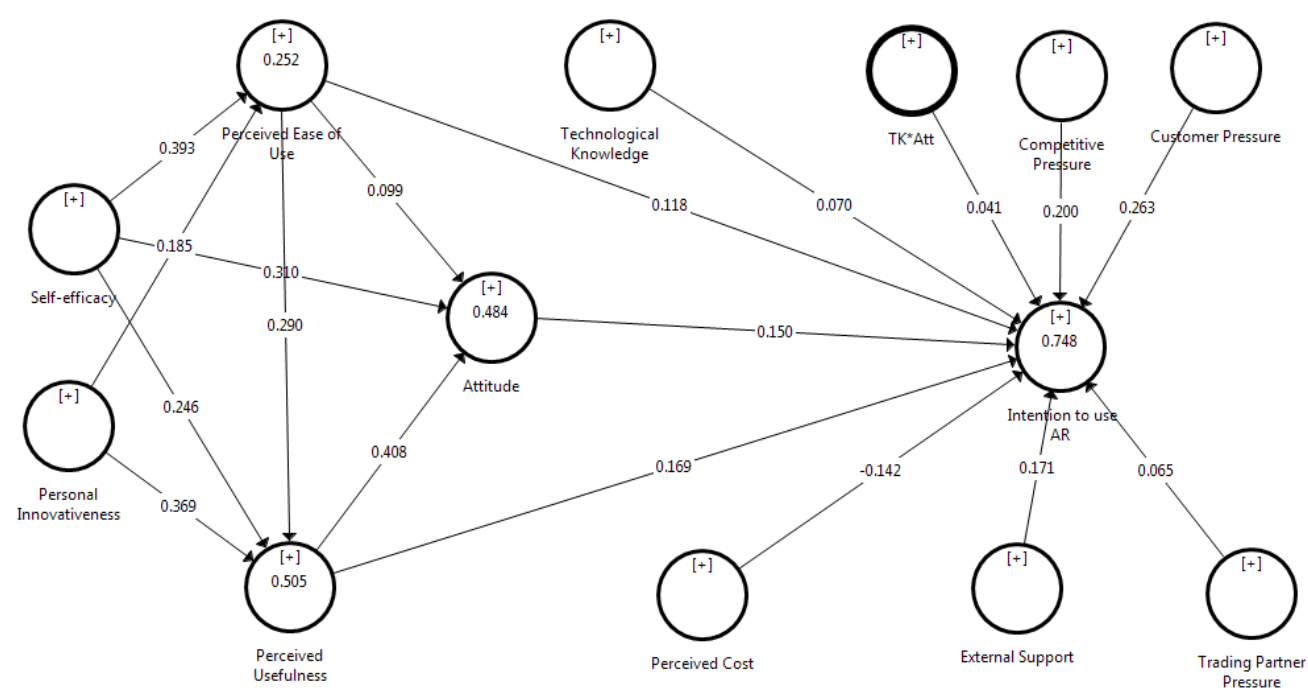

Figure 4. Moderation model.

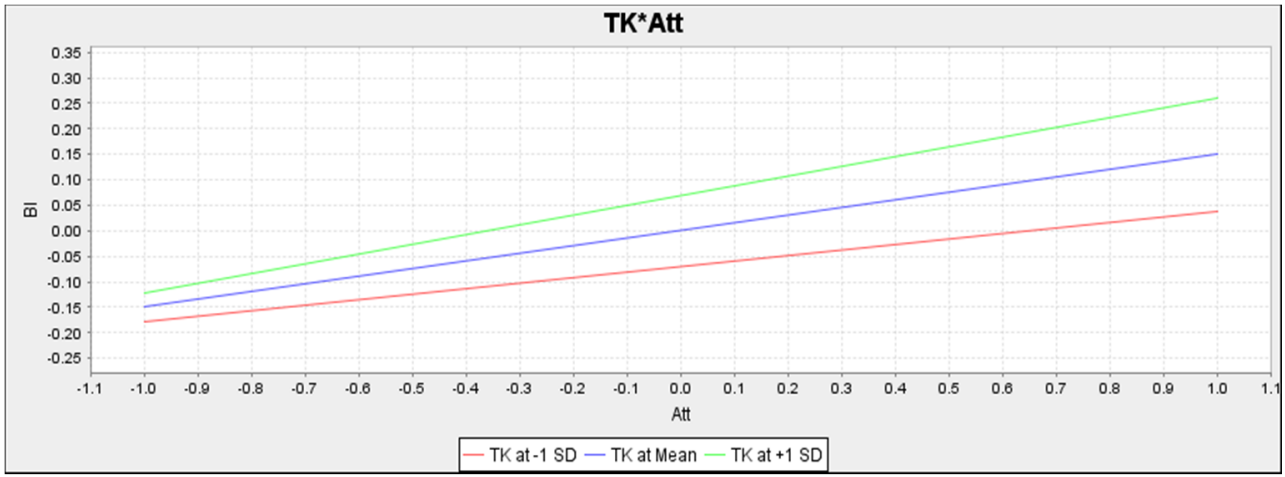

Figure 5. Slip model.

\section{Discussion: Augmented Reality Adoption and Open Innovation}

This study indicated that self-efficacy significantly affected perceived ease of use, supporting past research results [37,42]. The results confirmed that self-efficacy was the most important predictor affecting perceived ease of use. Results of this study concluded that self-efficacy had a significant effect on perceived usefulness and attitude. Previous studies [42,124] confirmed the present study's result. Consistent with the previous study, this study's results showed a significant relationship between personal innovativeness and perceived ease of use and perceived usefulness. Similar results were found in previous studies conducted by Kuo and Yen [48] and Yi et al. [51]. That means the higher the self-efficacy and personal innovation, the higher the perceived ease of use, usefulness, and attitude towards AR use.

As expected, perceived ease of use had a significant effect on perceived usefulness. This study's result was consistent with a previous study conducted by Sevim et al. [52] and Ha and Stoel [125]. On the other hand, the study's results showed that perceived ease of use did not significantly affect attitude. These results were inconsistent with previous studies conducted by Lim and Ting [54] and Yulihasri et al. [55]. This study's results confirmed the previous study conducted by Hernandez and Mazzon [56], Eriksson et al. [57], and Wang et al. [58]. The value for the association between perceived ease of use and the behavioral intention was significant.

Hypotheses 9 and 10 predicted the association between perceived usefulness and attitude and perceived usefulness and behavioral intention, and the result was in accordance. This result satisfied the past study $[22,63-65]$ in different areas. In addition, a significant 
association was found between attitude and behavioral intention. Previous studies by Yadav and Pathak [66] and Karjaluoto and Leppaniemi [67] matched what this study found. Similarly, this study's results also confirmed that perceived cost had a significant negative effect on behavioral intention. Previous researchers such as Mochoge [69] and Alam et al. [70] stated that perceived cost was one of the most critical predictors of behavioral intention. System development for providing an AR facility was needed, which incurred an extra charge for the retailers. Therefore, hypothesis 12 was also accepted in this study.

Competitor pressure is another important predictor affecting AR adoption intention among retailers in Malaysia. This study's result confirmed that there was a significant association between competitor pressure and behavioral intention. This study's results were consistent with the previous study done by Wanyoike et al. [74] and El-Gohary [73]. This study's results also confirmed the significant association between customer pressure and behavioral intention. We found that customer pressure was another significant predictor of behavioral intention. Technology knowledge was also found to have a significant influence on behavioral intention. This implied that AR adoption was positively related to user open innovation, customer open innovation, and engineer open innovation.

This study found that trading partners' and external pressure did not significantly affect behavioral intention. That was because retailers in Malaysia did not receive the product from one supplier, and not all suppliers accepted the technology in their business. On the other hand, external support had also no significant influence on behavioral intention. A possible reason is that the government in Malaysia has still not established an institution that would support this technology implementation in businesses. This study result was inconsistent with previous studies [73-76].

\section{Conclusions}

The study aimed to develop a comprehensive model for the AR behavioral intention. This study established an empirically tested model in the Malaysian context where it covered the limitations of the original TAM by increasing its explanatory power from 0.40 to 0.747 percent. The results showed that perceived usefulness, attitude, competitive pressure, customer pressure, and technological knowledge significantly affected the behavioral intention to use AR. At the same time, the perceived cost was significantly and negatively related to behavioral intention. The study also confirmed that trading partner pressure and external support were not related to behavioral intention to use AR in the retail store. The study revealed that self-efficacy was connected to the attitudes and perceived usefulness and perceived ease of use with perceived usefulness. In contrast, perceived usefulness affected attitude, and personal innovativeness affected perceived usefulness. The construct's perceived ease of use was not connected with the attitude towards accepting AR in Malaysia's Malaysian retail stores. The study further determined that attitude mediated the relationship between perceived usefulness and behavioral intention and self-efficacy and behavioral intention. However, attitude did not mediate the association between perceived ease of use and behavioral intention. Likewise, technology knowledge did not moderate the relationship between attitude and behavioral intention.

\subsection{Theoretical Contribution}

One of the main theoretical contributions of this study was the integration of open innovation-related factors and market-oriented technological factors with the existing TAM constructs for the full spectrum of understanding AR's behavioral intention. The added cognitive factors included self-efficacy, personal innovativeness, perceived cost, and technological knowledge. On the other hand, the market-oriented technological factors were external pressures from customer pressure and competitive pressure. Though these integrated factors were not completely new, it was missed in the recent retail sector literature to understand behavioral intention comprehensively. With the successful integration of the factors, the model explained external reasons, more specific individualistic causes, and existing technology-specific reasons predicting AR's behavioral intention in retail stores. 
However, this incorporation extended this model's explanatory power comprehensively aligned to Tarhini et al.'s [22] suggestion.

This research contributed to addressing the literature gap on two mediation effects of attitude within perceived usefulness, self-efficacy, and behavioral intention to adopt AR. This could be the reference point of future research, especially in SMEs' AR. Likewise, this research also filled the literature gap in the AR sector from SME entrepreneurial perspectives by providing some insight into retailers in emerging countries like Malaysia. Additionally, the model developed in this research could be applied to other new IT adoption contexts, such as the adoption intention of Artificial Intelligence. In the future, researchers can extend or replicate it as this research has its measurement scales validated by PLS statistical analysis.

\subsection{Implications for Practice}

While retailers attempt to develop open innovation-based business models through adopting AR technology in their retail business, retail managers should consider the factors affecting the adoption of such innovative technology. From an organizational context, this study showed that TAM constructs and other important open innovation factors might affect augmented reality usage in retailers, which retail managers need to consider while adopting this latest information technology. This study suggests that it is needed to consider the technology's ease of use and usefulness to ensure the successful implementation of augmented reality. This study's results also suggest that managers should also consider some other factors that significantly influence augmented reality implementation.

External support in the proposed model did not function as expected. Since this could be due to the unavailability of supporting institutions for implementing such latest technology in businesses, the Malaysian government and its responsible body should care for this missing aspect to materialize the upcoming fourth industrial revolution. We also suggest a future study that understands why this feature, which is usually necessary to introduce innovation, is not suitable for AR adoption. However, suppliers should also set up various customer service centers nearby for a stain-free AR experience.

This study's results indicated that operating cost is the key factor that influences AR acceptance. Concerning overhead expenses, administrators are also advised to introduce incentives to minimize escalated service charges or offer service bundles to get aspiring entrepreneurs. Managers should suggest, for example, delivering various packages of after-sales services and free installation charges.

Perceived ease of use was found significant for the behavioral intention that indicated ease of use-inspired businesses to adopt particular technology. The manufacturer of AR technology should give priority to ensure simplicity in terms of application, installation. Technical knowledge could enhance the adoption intention. Thus, the supplier should make an effort to educate managers through first-hand training or an interactive helpline at the time if needed. Likewise, AR had better use than prior practices. In the case of retail selling, the use of AR technology and its virtual trial rooms could lower the tendencies of returning products and customer dissatisfaction. Particularly, the chatbot facility installation could reduce the human efforts to answer queries.

Competitive pressure and Customer pressure are the external pressures influencing intention. Owners and managers should have a mechanism (opinion pool, feedbackseeking, reaction testing) to learn about customer's expectations about products and their delivery. This would help them attract new customers and to keep them exited and up to date. They should also continuously recheck their competitive advantages and instant upgrade on that.

\subsection{Limitation and Recommendation for Future Research}

No research is without limitation. In this study, we found some limitations which require further assessment and additional study. Firstly, this study focused mainly on eyewear and furniture retail stores in Malaysia. The literature showed that different 
technologies have distinct characteristics. Therefore, future researchers need to consider and verify this model using other respondents with technical knowledge. Secondly, this research only considered eyewear and furniture retailers; it is clear whether these analysis results could be generalized in the market context.

Further, this research model can apply to other retail business perspectives as perceived ease of use, perceived usefulness, and technological constructs can be related to particular product perspectives. Thirdly, this study was conducted in Malaysia, and their businesses are slow to adopt new technologies; therefore, it is not clear whether this research can be generalized to another country as other countries may have different cultures and different consumer behaviors. Thus, the study model developed in this research needs to be tested further in other countries using different samples, and this would further provide a higher robust test of this comprehensive model.

Author Contributions: Conceptualization, S.S.A. and Y.-H.H.; methodology, S.S.; software, M.M.; validation, S.S.A. and C.-Y.L.; formal analysis, C.-Y.L.; writing-original draft preparation, S.S.A., C.-Y.L. and M.M.; writing-review and editing, Y.-H.H. All authors have read and agreed to the published version of the manuscript.

Funding: This research received no external funding.

Institutional Review Board Statement: Ethical review and approval were waived for this study due to being not applicable for studies that do not involve humans or animals.

Informed Consent Statement: Informed consent was obtained from all subjects involved in the study.

Data Availability Statement: The data presented in this study are available on request from the corresponding author.

Conflicts of Interest: The authors declare no conflict of interest.

Appendix A. Questionnaire

\begin{tabular}{|c|c|}
\hline Items & Sources \\
\hline $\begin{array}{l}\text { Self-efficacy } \\
\text { - I am convinced that I will adopt augmented reality } \\
\text { in our online sales. } \\
\text { - I could figure out a way to implement augmented } \\
\text { reality in our business. } \\
\text { - I am confident of using augmented reality if I have } \\
\text { never used such a system before. }\end{array}$ & Chao [97] \\
\hline $\begin{array}{l}\text { Personal Innovativeness } \\
\text { - If I heard about new information technologies, I } \\
\text { would find ways to operate them. } \\
\text { - In general, I am ready to accept new technologies. } \\
\text { - I always try to use new information technologies } \\
\text { - } \quad \text { I usually keep an eye on emerging technology. }\end{array}$ & Janssen [101]; Fan et al. [126] \\
\hline $\begin{array}{l}\text { Perceived Ease of Use } \\
\text { - I think using augmented-reality-implemented } \\
\text { applications is easy. } \\
\text { - I think it is very simple to learn how to use } \\
\text { augmented reality applications. } \\
\text { - I think it does not require much effort to use an } \\
\text { augment-reality-implemented application. } \\
\text { I think the augmented-reality-implemented } \\
\text { application is clear and understandable. }\end{array}$ & Alam et al. [98]; Huang and Liao [99] \\
\hline
\end{tabular}




\begin{tabular}{cc}
\hline Items & Sources \\
\hline
\end{tabular}

\section{Perceived Usefulness}

- I can improve the online selling process with an augmented-reality-implemented application.

- My online selling process will be more efficient with an augmented-reality-implemented application.

- Augmented Reality will be helpful while selling online.

- $\quad$ Augmented reality will improve my ability while selling online.

\section{Attitude}

- I like the idea of selling online with augmented reality.

- I think that it is a good idea to sell online with augmented reality.

Alam et al. [98]

- I have a favorable attitude towards selling online with augmented reality.

Technological Knowledge

- I have a better understanding of AR applications.

- I have sufficient knowledge about how to handle AR applications.

Cost

- The initial set-up cost is high.

- Incur extra cost for hiring IT staff.

Alam et al. [70]

- Assessing costs and benefits are difficult.

Trading Partners Pressure

- Most of the trading partners of my company recommend and insist on adopting AR applications.

- If my company decides to adopt an AR application, then trading partners are also ready to adopt an AR application.

Pressure from competitors

- Our competitors have adopted AR technology.

- $\quad$ Our competitors are doing well using AR technology.

Salwani et al. [102]; Wanyoike et al. [74]

- Customers prefer online retailers who use AR technology.
Pressure from customers

- $\quad$ Our customers expect us to use AR technology.

- Our customers demand that we use AR technology.

- $\quad$ The use of AR technology is something that would make the customer happy.

\section{External Support}

- The existing policy related to AR applications is quite suitable to support the adoption.

- $\quad$ The government assists and supports retail organizations to adopt AR applications.

\section{Behavioral Intention}

- I will consider augmented reality while selling online.

- I think it will be worth it for me to use augmented reality in online selling.
Wanyoike et al. [74]; Zhu and Kraemer [100]
- Regularly, I will use augmented reality in online selling. 


\section{References}

1. Imbert, N.; Vignat, F.; Kaewrat, C.; Boonbrahm, P. Adding Physical Properties to 3D Models in Augmented Reality for Realistic Interactions Experiments. Procedia Comput. Sci. 2013, 25, 364-369. [CrossRef]

2. Lazim, N.A.M.; Rahman, K.A.A.A. State-of-the-Art Responses on Augmented Reality Application in Malaysia. Int. J. Sustain. Trop. 2015, 8, 28-34.

3. Ng, C.C.; Ramasamy, C. Augmented Reality Marketing in Malaysia-Future Scenarios. Soc. Sci. 2018, 7, 224. [CrossRef]

4. Coyne, T. Augmented Reality Helps Consumers See Shopping in a Whole New Way. Available online: https://www.jll.com.co/ en/trends-and-insights/workplace/augmented-reality-helps-consumers-see-shopping-in-a-whole-new-way (accessed on 18 February 2020).

5. Ridden, P. IKEA Catalog Uses Augmented Reality to Give a Virtual Preview of Furniture in a Room. New Atlas. 2013. Available online: https:/ / newatlas.com/ikea-augmented-reality-catalog-app/28703/ (accessed on 18 February 2020).

6. Markets and Markets. Augmented Reality in Retail Market by Offering (Hardware and Software), Device Type (HeadMounted, Smart AR Mirror), Application (Try-On Solution, Planning \& Designing), Retail Type (Furniture, Beauty \& Cosmetics), and Geography_Global Forecast to 2023. 2017. Available online: https://www.marketsandmarkets.com/Market-Reports/ augmented-reality-retail-market-77516130.html (accessed on 18 February 2020).

7. Yun, J.J.; Yang, J.; Park, K. Open Innovation to Business Model: New Perspective to Connect between Technology and Market. Sci. Technol. Soc. 2016, 21, 1-25. [CrossRef]

8. Wafa, S.N.; Hashim, E. Adoption of Mobile Augmented Reality Advertisements by Brands in Malaysia. Procedia Soc. Behav. Sci. 2016, 219, 762-768. [CrossRef]

9. Zulkifli, A.N.; Alnagrat, A.J.A.; Mat, R.C. Development and Evaluation of i-Brochure: A Mobile Augmented Reality Application. J. Telecommun. Electron. Comput. Eng. 2016, 8, 145-150.

10. Goebert, C.; Greenhalgh, G.P. A New Reality: Fan Perceptions of Augmented Reality Readiness in Sports Marketing. Comput. Hum. Behav. 2020, 106, 106231. [CrossRef]

11. Li, H.; Gupta, A.; Zhang, J.; Flor, N. Who Will Use Augmented Reality? An Integrated Approach Based on Text Analytics and Field Survey. Eur. J. Oper. Res. 2020, 281, 502-516. [CrossRef]

12. Shin, D. How Does Immersion Work in Augmented Reality Games? A User-centric View of Immersion and Engagement. Inf. Commun. Soc. 2019, 22, 1212-1229. [CrossRef]

13. Cabero-Almenara, J.; Fernández-Batanero, J.M.; Barroso-Osuna, J. Adoption of Augmented Reality Technology by University Students. Heliyon 2019, 5, e01597. [CrossRef]

14. Yim, M.Y.C.; Park, S.Y. I Am Not Satisfied with My Body, so I Like Augmented Reality (AR): Consumer Responses to AR-based Product Presentations. J. Bus. Res. 2019, 100, 581-589. [CrossRef]

15. McLean, G.; Wilson, A. Shopping in the Digital World: Examining Customer Engagement through Augmented Reality Mobile Applications. Comput. Hum. Behav. 2019, 101, 210-224. [CrossRef]

16. Rauschnabel, P.A.; Rossmann, A.; Tom Dieck, M.C. An Adoption Framework for Mobile Augmented Reality Games: The Case of Pokémon Go. Comput. Hum. Behav. 2017, 76, 276-286. [CrossRef]

17. Perannagari, K.T.; Chakrabarti, S. Factors Influencing Acceptance of Augmented Reality in Retail: Insights from Thematic Analysis. Int. J. Retail. Distrib. Manag. 2019, 48, 18-34. [CrossRef]

18. Fan, X.; Chai, Z.; Deng, N.; Dong, X. Adoption of Augmented Reality in Online Retailing and Consumers' Product Attitude: A Cognitive Perspective. J. Retail. Consum. Serv. 2020, 53, 101986. [CrossRef]

19. Yang, S.; Carlson, J.R.; Chen, S. How Augmented Reality Affects Advertising Effectiveness: The Mediating Effects of Curiosity and Attention toward the Ad. J. Retail. Consum. Serv. 2020, 54, 102020. [CrossRef]

20. Lee, J.; Kim, J.; Choi, J.Y. The Adoption of Virtual Reality Devices: The Technology Acceptance Model Integrating Enjoyment, Social Interaction, and Strength of the Social Ties. Telemat. Inform. 2019, 39, 37-48. [CrossRef]

21. Kim, T.; Chiu, W. Consumer Acceptance of Sports Wearable Technology: The Role of Technology Readiness. Int. J. Sports Mark. Spons. 2019, 20, 109-126. [CrossRef]

22. Chuah, S.H.W.; Rauschnabel, P.A.; Krey, N.; Nguyen, B.; Ramayah, T.; Lade, S. Wearable Technologies: The Role of Usefulness and Visibility in Smart Watch Adoption. Comput. Hum. Behav. 2016, 65, 276-284. [CrossRef]

23. Tarhini, A.; Hone, K.; Liu, X.; Tarhini, T. Examining the Moderating Effect of Individual Level Cultural Values on Users' Acceptance of E-learning in Developing Countries: A structural Equation Modeling of an Extended Technology Acceptance Model. Int. Learn. Environ. 2017, 25, 306-328. [CrossRef]

24. Legris, P.; Ingham, J.; Collerette, P. Why do People Use Information Technology? A Critical Review of the Technology Acceptance Model. Inf. Manag. 2003, 40, 191-204. [CrossRef]

25. Fishbein, M.; Ajzen, I. Belief, Attitude, Intention, and Behavior: An Introduction to Theory and Research; Addison-Wesley: Boston, MA, USA, 1975.

26. Ajzen, I. The Theory of Planned Behavior. Org. Behav. Hum. Decis. Proc. 1991, 50, 179-211. [CrossRef]

27. Rogers, E.M. Diffusion of Innovations, 5th ed.; Simon \& Shuster: New York, NY, USA, 2003.

28. Davis, F.D. Technology Acceptance Model for Empirically Testing New End-User Information Systems: Theory and Results. Doctoral Dissertation, The Sloan School of Management, MIT, Cambridge, MA, USA, 1986. 
29. Davis, F.D.; Bagozzi, R.P.; Warshaw, P.R. User Acceptance of Computer Technology: A Comparison of Two Theoretical Models. Manag. Sci. 1989, 35, 982-1003. [CrossRef]

30. Venkatesh, V.; Thong, J.; Xu, X. Consumer Acceptance and Use of Information Technology: Extending the Unified Theory of Acceptance and Use of Technology. MIS Q. 2012, 36, 157-178. [CrossRef]

31. DeLone, W.H.; McLean, E.R. The DeLone and McLean Model of Information Systems Success: A Ten-year Update. J. Manag. Inf. Syst. 2003, 19, 9-30.

32. Bailey, J.E.; Pearson, S.W. Development of a Tool for Measuring and Analyzing Computer User Satisfaction. Manag. Sci. 1983, 29, 530-545. [CrossRef]

33. McFarland, D.J.; Hamilton, D. Adding Contextual Specificity to the Technology Acceptance Model. Comput. Hum. Behav. 2006, 22, 427-447. [CrossRef]

34. Wu, W. Developing an Explorative Model for SaaS Adoption. Exp. Syst. Appl. 2011, 38, 15057-15064. [CrossRef]

35. Garaca, Z. Factors Related to the Intended Use of ERP Systems. Management 2011, 16, $23-42$.

36. Pramana, E. Determinants of the Adoption of Mobile Learning Systems among University Students in Indonesia. J. Inf. Technol. Edu. Res. 2018, 17, 365-398. [CrossRef]

37. Compeau, D.R.; Higgins, C.A. Application of Social Cognitive Theory to Training for Computer Skills. Inf. Syst. Res. 1995, 6,118-143. [CrossRef]

38. Bandura, A. Self-efficacy: Toward a Unifying Theory of Behavioral Change. Psychol. Rev. 1977, 84, 191-215. [CrossRef]

39. Malliari, A. IT Self-efficacy and Computer Competence of LIS Students. Elec. Lib. 2012, 30, 608-622. [CrossRef]

40. Hauser, R.; Paul, R.; Bradley, J. The Impact of Culture and Computer Self-efficacy in an Online Training Environment. Procedia Acad. Inf. Manag. Sci. 2008, 12, 19-22.

41. John, S.P. Influence of Computer Self-Efficacy on Information Technology Adoption. Int. J. Inf. Technol. 2013, 19, 1-13.

42. Budu, K.W.A.; Yinping, M.; Mireku, K.K. Investigating the Effect of Behavioral Intention on E-learning Systems Usage: Empirical Study on Tertiary Education Institutions in Ghana. Med. J. Soc. Sci. 2018, 9, 201-216. [CrossRef]

43. Bandura, A. Self-Efficacy in Changing Societies; Cambridge University Press: New York, NY, USA, 1995.

44. Agarwal, R.; Prasad, J. A Conceptual and Operational Definition of Personal Innovativeness in the Domain of Information Technology. Inf. Syst. Res. 1998, 9, 204-215. [CrossRef]

45. Luo, X.; Li, H.; Zhang, J.; Shim, J.P. Examining Multi-dimensional Trust and Multi-faceted Risk in Initial Acceptance of Emerging Technologies: An Empirical Study of Mobile Banking Services. Decis. Support Syst. 2010, 49, 222-234. [CrossRef]

46. Aldás-Manzano, J.; Ruiz-Mafé, C.; Sanz-Blas, S. Exploring Individual Personality Factors as Drivers of M-shopping Acceptance. Ind. Manag. Data Syst. 2009, 109, 739-757. [CrossRef]

47. Zarmpou, T.; Saprikis, V.; Markos, A.; Vlachopoulou, M. Modeling Users' Acceptance of Mobile Services. Ind. Manag. Data Syst. 2012, 12, 225-248. [CrossRef]

48. Kuo, Y.; Yen, S. Computers in Human Behavior Towards an Understanding of the Behavioral Intention to Use 3G Mobile Value-added Services. Comput. Hum. Behav. 2009, 25, 103-110. [CrossRef]

49. Kim, C.; Mirusmonov, M.; Lee, I. An Empirical Examination of Factors Influencing the Intention to Use Mobile Payment. Comput. Hum. Behav. 2010, 26, 310-322. [CrossRef]

50. Lu, J.; Yao, J.E.; Yu, C. Personal Innovativeness, Social Influences and Adoption of Wireless Internet Services via Mobile Technology. J. Strateg. Inf. Syst. 2005, 14, 245-268. [CrossRef]

51. Yi, M.Y.; Fiedler, K.D.; Park, J.S. Understanding the Role of Individual Innovativeness in the Acceptance of IT-based Innovations: Comparative Analyses of Models and Measures. Decis. Sci. 2006, 37, 393-426. [CrossRef]

52. Sevim, N.; Yuncu, D.; Hall, E.E. Analysis of the Extended Technology Acceptance Model in Online Travel Products. J. Int. Appl. Manag. 2017, 8, 45-61. [CrossRef]

53. Ha, S.; Stoel, L. Consumer E-Shopping Acceptance: Antecedents in a Technology Acceptance Model. J. Bus. Res. 2009, 62, 565-571. [CrossRef]

54. Lim, W.M.; Ting, D.H. E-Shopping: An Analysis of the Technology Acceptance Model. Mod. Appl. Sci. 2012, 6, 49-62. [CrossRef]

55. Yulihasri, E.; Islam, M.A.; Daud, K.A.K. Factors that Influence Customers' Buying Intention on Shopping Online. Int. J. Mark. Stud. 2010, 3, 128-139.

56. Hernandez, J.M.C.; Mazzon, J.A. Adoption of Internet Banking: Proposition and Implementation of an Integrated Methodology Approach. Int. J. Bank Mark. 2007, 25, 72-88. [CrossRef]

57. Eriksson, K.; Kerem, K.; Nilsson, D. Customer Acceptance of Internet Banking in Estonia. Int. J. Bank Mark. 2005, 23, 200-216. [CrossRef]

58. Wang, Y.S.; Wang, Y.M.; Lin, H.H.; Tang, T.I. Determinants of User Acceptance of Internet Banking: An Empirical Study. Int. J. Ser. Ind. Manag. 2003, 14, 501-519. [CrossRef]

59. Selamat, Z.; Jaffar, N.; Ong, B.H. Technology Acceptance in Malaysian Banking Industry. Eur. J. Econ. Financ. Adm. Sci. 2009, $1,143-155$.

60. Fagan, M.; Kilmon, C.; Pandey, V. Exploring the Adoption of a Virtual Reality Simulation: The Role of Perceived Ease of Use, Perceived Usefulness and Personal Innovativeness. Campus-Wide Inf. Syst. 2012, 29, 117-127. [CrossRef]

61. Broom, D.R.; Lee, K.Y.; Lam, M.H.S.; Flint, S.W. Gotta Catch ‘em All or Not Enough Time: Users Motivations for Playing Pokémon Go-and Non-users' Reasons for Not Installing. Health Psychol. Res. 2019, 7, 1-9. [CrossRef] [PubMed] 
62. Hsu, C.L.; Lin, J.C.C. What Drives Purchase Intention for Paid Mobile Apps? An Expectation Confirmation Model with Perceived Value. Electr. Comme. Res. Appl. 2015, 14, 46-57. [CrossRef]

63. Sumak, B.; Heicko, M.; Pusnik, M.; Polancic, G. Factors Affecting Acceptance and Use of Moodle: An Empirical Study Based on TAM. Informatica 2011, 35, 91-100.

64. Dutot, V.; Bhatiasevi, V.; Bellallahom, N. Applying the Technology Acceptance Model in a Three-country Study of Smart Watch Adoption. J. High Technol. Manag. Res. 2019, 30, 1-14. [CrossRef]

65. Kalantari, M. Consumers' Adoption of Wearable Technologies: Literature Review, Synthesis, and Future Research Agenda. Int. J. Technol. Mark. 2017, 12, 274-307. [CrossRef]

66. Yadav, R.; Pathak, G.S. Determinants of Consumers' Green Purchase Behavior in a Developing Nation: Applying and Extending the Theory of Planned Behavior. Ecol. Econ. 2017, 134, 114-122. [CrossRef]

67. Karjaluoto, H.; Leppaniemi, M. Social Identity for Teenagers: Understanding Behavioral Intention to Participate in Virtual World Environment. J. Theor. Appl. Electron. Commer. Res. 2013, 8, 1-16. [CrossRef]

68. Chang, H.H.; Wang, I.C. An Investigation of User Communication Behavior in Computer Mediated Environment. Comput. Hum. Behav. 2008, 24, 2336-2356. [CrossRef]

69. Mochoge, O.C. SMES' Adoption of Web-based Marketing: Empirical Evidence from Kenya. Int. J. Comput. Sci. Issue 2014, 11, 226-236.

70. Alam, S.S.; Ali, M.Y.; Jani, M.F.M. An Empirical Study of Factors Affecting Electronic Commerce Adoption among SMEs in Malaysia. J. Bus. Econ. Manag. 2011, 12, 375-399. [CrossRef]

71. Luarn, P.; Lin, H.H. Toward an Understanding of the Behavioral Intention to Use Mobile Banking. Comput. Hum. Behav. 2005, 21, 873-891. [CrossRef]

72. Hayes, T.P., Jr. Predicting Information Technology Adoption in Small Businesses: An Extension of the Technology Acceptance Model. Acad. Inf. Manag. Sci. J. 2012, 15, 37-46.

73. El-Gohary, H. Factors Affecting E-marketing Adoption and Implementation in Tourism Firms: An Empirical Investigation of Egyptian Small Tourism Organisations. Tour. Manag. 2012, 33, 1256-1269. [CrossRef]

74. Wanyoike, D.M.; Mukulu, E.; Waititu, A.G. ICT Attributes as Determinants of e-commerce Adoption by Formal Small Enterprises in Urban Kenya. Int. J. Bus. Soc. Sci. 2012, 3, 65-74.

75. Matikiti, R.; Mpinganjira, M.; Roberts-Lombard, M. Application of the Technology Acceptance Model and the TechnologyOrganisation-Environment Model to Examine Social Media Marketing Use in the South African Tourism Industry. S. Afr. J. Inf. Manag. 2018, 20, 1-12. [CrossRef]

76. Sharma, A.; Citurs, A.; Konsynski, B. Strategic and Institutional Perspectives in the Adoption and Early Integration of Radio Frequency Identification (RFID). In Proceedings of the 2007 40th Annual Hawaii International Conference on System Sciences (HICSS 2007), Big Island, HI, USA, 3-6 January 2007.

77. Paydar, S.; Endut, I.R.; Yahya, S.; Rahman, S.H.A. Environmental Factors Influencing the Intention to Adopt RFID Technology in Retail Industry: An Empirical Study. Asia-Pac. J. Manag. Res. Innov. 2014, 10, 13-26. [CrossRef]

78. To, M.L.; Ngai, E.W.T. Predicting the Organisational Adoption of B2C e-commerce: An Empirical Study. Ind. Manag. Data Syst. 2006, 106, 1133-1147. [CrossRef]

79. Hasani, T.; Bojei, J.; Dehghantanha, A. Investigating the Antecedents to the Adoption of SCRM Technologies by Start-up Companies. Telemat. Inform. 2017, 34, 655-675. [CrossRef]

80. Ueki, Y. Customer Pressure, Customer-Manufacturer-Supplier Relationships, and Quality Control Performance. J. Bus. Res. 2016, 69, 2233-2238. [CrossRef]

81. Maduku, D.K.; Mpinganjira, M.; Duh, H. Understanding Mobile Marketing Adoption Intention by South African SMEs: A Multi-Perspective Framework. Int. J. Inf. Manag. 2016, 36, 711-723. [CrossRef]

82. Mukred, M.; Yusof, Z.M.; Asma'Mokhtar, U.; Fauzi, F. A Framework for Electronic Records Management System Adoption in the Higher Professional Education: Individual, Technological and Environmental Factors. In Proceedings of the International Conference of Reliable Information and Communication Technology, Kuala Lumpur, Malaysia, 23-24 June 2018; Springer: Cham, Switzerland, 2018; pp. 840-849.

83. Ngah, A.H.; Zainuddin, Y.; Thurasamy, R. Applying the TOE Framework in the Halal Warehouse Adoption Study. J. Islamic Account. Bus. Res. 2017, 8, 161-181. [CrossRef]

84. Lian, J.-W.; Yen, D.C.; Wang, Y.-T. An Exploratory Study to Understand the Critical Factors Affecting the Decision to Adopt Cloud Computing in Taiwan Hospital. Int. J. Inf. Manag. 2014, 34, 28-36. [CrossRef]

85. Wu, X.; Subramaniam, C. New Understanding of RFID Adoption and Infusion in Retail Supply Chain. In Proceedings of the 2009 42nd Hawaii International Conference on System Sciences (HICSS'09), Waikoloa, HI, USA, 5-8 January 2009; pp. 1-10. [CrossRef]

86. Lin, H.F.; Lin, S.M. Determinants of E-business Diffusion: A Test of the Technology Diffusion Perspective. Technovation 2008, 28, 135-145. [CrossRef]

87. Crook, C.W.; Kumar, R.L. Electronic Data Interchange: A Multi-Industry Investigation Using Grounded Theory. Inf. Manag. 1998, 34, 75-89. [CrossRef]

88. Van den Berg, J.; Van der LIngen, E. An Empirical Study of the Factors Affecting the Adoption of Mobile Enterprise Applications. S. Afr. J. Ind. Eng. 2019, 30, 124-146. [CrossRef]

89. Lichtenthaler, U. Toward an Innovation-based perspective on company performance. Manag. Deceic. 2016, 54, 66-87. 
90. Yaqub, J.; Bello, H.T.; Adenuga, I.A.; Ogundeji, M.O. The cashless policy in Nigeria: Prospects and challenges. Int. J. Hum. Soc. Sci. 2013, 3, 200-212.

91. Venkatesh, V.; Morris, M.G.; Davis, G.B.; Davis, F.D. User Acceptance of Information Technology: Toward a Unified View. MIS Q 2003, 27, 425-478. [CrossRef]

92. Schaper, L.K.; Pervan, G.P. An Investigation of Factors Affecting Technology Acceptance and Use Decisions by Australian Allied Health Therapists. In Proceedings of the 2007 40th Annual Hawaii International Conference on System Sciences (HICSS 2007), Waikoloa, Big Island, HI, USA, 3-6 January 2007.

93. Gajanayake, R.; Sahama, T.; Iannella, R. The Role of Perceived Usefulness and Attitude on Electronic Health Record Acceptance an Empirical Investigation Using Response Surface Analysis. Int. J. E-Health Med. Commun. 2014, 5, 108-119. [CrossRef]

94. Krishanan, D.; Teng, K.L.L.; Khalidah, S. Mediating Effects of Attitude towards Consumers' Perceived Interactivity in Using Mobile Banking. J. Glob. Bus. Soc. Entr. 2016, 3, 95-106.

95. Richman, W.L.; Kiesler, S.; Weisband, S.; Drasgow, F. A Meta-analytic Study of Social Desirability Distortion in Computeradministered Questionnaires, Traditional Questionnaires, and Interviews. J. Appl. Psychol. 1999, 84, 754-775. [CrossRef]

96. Cohen, J. Statistical Power Analysis for the Behavioral Sciences, 2nd ed.; Hillside: Erlbaum, NJ, USA, 1988.

97. Chao, C.M. Factors Determining the Behavioral Intention to Use Mobile Learning: An Application and Extension of the UTAUT Model. Front. Psychol. 2019, 10, 1652. [CrossRef] [PubMed]

98. Alam, S.S.; Omar, N.A.; Ariffin, A.A.M.; Hashim, N.M.H.N. Integrating TPB, TAM and DOI Theories: An Empirical Evidence for the Adoption of Mobile Banking among Customers in Klang Valley, Malaysia. Int. J. Bus. Manag. Sci. 2018, 8, 385-403.

99. Huang, T.; Liao, S. A Model of Acceptance of Augmented-Reality Interactive Technology: The Moderating Role of Cognitive Innovativeness. Electric. Commer. Res. 2015, 15, 269-295. [CrossRef]

100. Zhu, K.; Kraemer, K.L. Post-adoption Variations in Usage and Value of e-business by Organisations: Cross-country Evidence from the Retails Industry. Inf. Syst. Res. 2005, 16, 61-84. [CrossRef]

101. Janssen, C. Consumer Acceptance of Mobile Augmented Reality Shopping Applications in Stationary Retail Trade. Bachelor Thesis, Mid Sweden University, Östersund, Sweden, 2018. Available online: http://www.diva-portal.org/smash/get/diva2: 1232271/FULLTEXT01.pdf (accessed on 31 January 2020).

102. Salwani, M.I.; Marthandan, G.; Norzaidi, M.D.; Chong, S.C. E-commerce Usage and Business Performance in the Malaysian Tourism Sector: Empirical Analysis. Inf. Manag. Comput. Secur. 2009, 17, 166-185. [CrossRef]

103. Alam, S.S.; Sayuti, M.N. Applying the Theory of Planned Behavior (TPB) in Halal Food Purchasing. Int. J. Commer. Manag. 2011, 21, 8-20. [CrossRef]

104. Podsakoff, P.M.; MacKenzie, S.B.; Lee, J.Y.; Podsakoff, N.P. Common Method Biases in Behavioral Research: A Critical Review of the Literature and Recommended Remedies. J. Appl. Psychol. 2003, 88, 879-903. [CrossRef]

105. Harman, H.H. Modern Factor Analysis; University Press of Chicago: Chicago, IL, USA, 1967.

106. Lowry, P.B.; Gaskin, J. Partial Least Squares (PLS) Structural Equation Modeling (SEM) for building and testing behavioral causal theory: When to choose it and how to use it. IEEE Trans. Prof. Commun. 2014, 57, 123-146. [CrossRef]

107. Ringle, C.M.; Sarstedt, M.; Mooi, E.A. Response-based Segmentation Using Finite Mixture Partial Least Squares. In Data Mining: Special Issue in Annals of Information Systems; Stahlbock, R., Crone, S.F., Lessmann, S., Eds.; Springer: Boston, MA, USA, 2010; pp. $19-49$.

108. Ringle, C.M.; Sarstedt, M. Gain More Insight from Your PLS-SEM Results: The Importance-performance Map Analysis. Ind. Manag. Data Syst. 2016, 116, 1865-1886. [CrossRef]

109. Ringle, C.M.; Wende, S.; Will, A. SmartPLS 2.0 (Beta) Hamburg. 2005. Available online: www.smartpls.de (accessed on 30 June 2020).

110. Hair, J.F.; Black, W.C.; Babin, B.J.; Anderson, R.E. Multivariate Data Analysis, 7th ed.; Pearson Education: Upper Saddle River, NJ, USA, 2010.

111. Hair, J.F., Jr.; Hult, G.T.M.; Ringle, C.; Sarstedt, M. A Primer on Partial Least Squares Structural Equation Modeling (PLS-SEM), 2nd ed.; SAGE Publications: New York, NY, USA, 2016.

112. Ringle, C.M.; Sarstedt, M.; Straub, D. A Critical Look at the Use of PLS-SEM in MIS Quarterly. MIS Q. 2012, 36, 3-13. [CrossRef]

113. Tenenhaus, M.; Vinzi, V.E.; Chatelin, Y.M.; Lauro, C. PLS Path Modeling. Comput. Stat. Data Anal. 2005, 48, 159-205. [CrossRef]

114. Fornell, C.; Larcker, D.F. Evaluating Structural Equation Models with Unobservable Variables and Measurement Error. J. Mark. Res. 1981, 18, 39-50. [CrossRef]

115. Henseler, J.; Ringle, C.M.; Sarstedt, M. A New Criterion for Assessing Discriminant Validity in Variance-based Structural Equation Modeling. J. Acad. Mark. Sci. 2015, 43, 115-135. [CrossRef]

116. Kline, R.B. Principles and Practice of Structural Equation Modeling, 4th ed.; Guilford Press: New York, NY, USA, 2016.

117. Kleinbaum, D.G.; Kupper, L.L.; Muller, K.E. Applied Regression Analysis and Other Multivariable Methods; Duxbury Press: Belmont, CA, USA, 1988.

118. Santosa, P.; Wei, K.; Chan, H. User Involvement and User Satisfaction with Information-seeking Activity. Eur. J. Inf. Syst. 2005, 14, 361-370. [CrossRef]

119. Falk, R.F.; Miller, N.B. A Primer for Soft Modeling; University of Akron Press: Akron, OH, USA, 1992.

120. Stone, M. Cross-validatory Choice and Assessment of Statistical Predictions. J. R. Stat. Soc. Ser. B 1974, 36, 111-133. [CrossRef]

121. Geisser, S. A Predictive Approach to the Random Effect Model. Biometrika 1974, 61, 101-107. [CrossRef] 
122. Hayes, A.F.; Preacher, K.J. Quantifying and Testing Indirect Effects in Simple Mediation Models when the Constituent Paths Are Nonlinear. Multivar. Behav. Res. 2010, 45, 627-660. [CrossRef] [PubMed]

123. Hair, J.F.; Ringle, C.M.; Sarstedt, M. Partial Least Squares Structural Equation Modeling: Rigorous Applications, Better Results and Higher Acceptance. Long Range Plan. 2013, 46, 1-12. [CrossRef]

124. Alammary, A.; Sheard, J.; Carbone, A. Blended Learning in Higher Education: Three Different Design Approaches. Australas. J. Educ. Technol. 2014, 30, 440-454. [CrossRef]

125. Ha, Y.; Stoel, L. Internet Apparel Shopping Behaviors: The Influence of General Innovativeness. Int. J. Retail Distrib. Manag. 2004, 32, 377-385. [CrossRef]

126. Fan, W.; Liu, J.; Zhu, S.; Pardalos, P.M. Investigating the Impacting Factors for the Healthcare Professionals to Adopt Artificial Intelligence-based Medical Diagnosis Support System (AIMDSS). Ann. Oper. Res. 2020, 294, 567-592. [CrossRef] 